\title{
Conceptual study for long-term monitoring of chemotherapeutic induced cell reactions by ESPI
}

\author{
Konzeptionelle Studie zur Langzeit-Untersuchung an Chemotherapeutika-induzierten \\ Zellreaktionen mittels ESPI
}

https://doi.org/10.1515/teme-2017-0100

Received August 4, 2017; revised September 29, 2017; accepted

October 10, 2017

\begin{abstract}
During the last years, various approaches on an individualized drug therapy for benign cells have been researched. However, due to the complex topic a universal approach has not been found up until this point. Commonly, the effect of cytotoxic drugs on benign cells is in most cases the same compared to regular cells while the actual effect on patient still can't be predicted. In order to reduce unwanted side effects or unspecific drug reactions a test system for patients which allows to analyse the interaction between cytotoxic agents and the targeted cells is needed. Furthermore, this should also include an adequate measurement system which is capable to work in a natural environment and without any additional preparation. In terms of this work, a first proof of concept with different benign cells and cytotoxic agents is presented while monitoring the obtained displacement using electronic speckle pattern interferometry (ESPI).
\end{abstract}

Keywords: Interferometry, ESPI, anticancer drugs, cellular displacements.

Zusammenfassung: In den vergangenen Jahren wurde bereits eine Vielzahl von vielversprechende Ansätze für eine individualisierte Therapie von benignen Zellen erforscht. Jedoch konnte bedingt durch die Komplexität der

\footnotetext{
*Corresponding author: Josefine Johanna Gottschalk, Technical University of Applied Science Wildau, Institute for Materials, Development and Production, Hochschulring 1, 15745 Wildau, Germany, e-mail: gottschalk@th-wildau.de Carsten Stollfuß, Kai-Henning Lietzau, Andreas H. Foitzik: Technical University of Applied Science Wildau, Institute for Materials, Development and Production, Hochschulring 1, 15745 Wildau, Germany

Maria Richetta: Department of Industrial Engineering, University of Rome "Tor Vergata", Via del Politecnico 1, 00133 Rome, Italy
}

zu grundlegenden zellbasierten Interaktionen bisher kein allgemeingültiger Ansatz etabliert werden. Grundsätzlich ist die Wirkungsweise von zytotoxischen Medikamenten auf benigne und gesunden Zellen nahezu identisch, jedoch lässt sich die direkte Reaktion am Patienten weiterhin nicht vorhersagen. Um Nebeneffekte und das Risiko von unspezifischen Reaktionen für den Patienten zu verringern ist daher ein Analysesystem notwendig, welches in der Lage ist die hervorgerufene Interaktion zwischen zytotoxischen Medikamenten und dem Zielzellen zu untersuchen. Weiterhin sollte dies auch ein Messsystem umfassen, dass in einer für die Zellen natürlichen Umgebung und ohne weitere Präparation der zu untersuchenden Proben arbeiten kann. Im Rahmen der vorliegenden Arbeit erfolgte daher ein erster Proof-of-Concept mit unterschiedlichen benignen Zellen in Verbindung mit ausgewählten zytotoxischen Wirkstoffen. Zur Auswertung der induzierten zellulären Verformung wurde die Elektronische Speckle Muster Interferometrie (kurz. ESPI) verwendet.

Schlüsselwörter: Interferometrie, ESPI, Chemotherapeutika, zelluläre Verformungen.

\section{Introduction}

Various studies regarding the behavior of cancer or the research for new therapeutic methods are carried out all over the globe. However, cancer can be very specific and type dependent, which often requires a different approach for the treatment. Established approaches that treats one specific cancer have no influence on other types. In this case, a personalized treatment for the patient is required. One of the common approaches is the application of chemotherapeutical agents. In order to analyze the toxicity as well as the potency of these substance the behavior of cancer cell during the treatment must be observed. For this purpose benign model cells are often utilized, while keeping in mind that the numerous metabolic pathways of humans and model organisms can differ dramatically, as the 
TGN1412 study from the year 2012 proved. While the in vivo experiments yielded promising results which lead to an approval for a Phase I study, the drug treatment caused serious side effects within only a few minutes. The reason for this was a difference in the amino acid sequence of the CD28 molecule. Especially since this study it was shown that an adaptation of the cytostatic effect of in vivo experiments can have severe consequences for the patients [1]. Consequently, in order to examine the actual effect of a cytotoxic agent on a single patient, a test system is required which provides a long term analyzation of the induced cellular behavior. In initial experiments selected cells were treated with cytotoxic agents while their interaction was observed by ESPI. Therefore, a test setup was developed, which combined an adaptation of optical measurement technique and an almost natural environment for the benign cells. The first experiments were carried out for the development of reference models in terms of the induced surface displacement of the cellular bodies. Afterwards, it was already possible to identify and validate individual stages of the cellular reaction.

\section{Theoretical background}

The institute of medicine (US) Committee on Quality of Health Care in America define that health care should be safe, effective, patient-centered, timely, efficient and equitable [2]. In order to ensure this, scientists research the complex development of cancer and promising treatment strategies. One of these strategies is the chemotherapy which is defined as a treatment of cancer using specific chemical agents or drugs that are selectively destructive to malignant cell sand tissues [3]. As already mentioned, every kind of cancer and patient is unique. Thus, an almost successful treatment could be ineffective for the next patient. In most cases, this effect is caused by a chemical resistance against the applied anticancer drug. The formation or increase of unwanted side effects which weaken the patient unnecessarily can be additional consequences. Nowadays, a great variety of anticancer drugs exists which have been primarily evaluated utilizing in vitro or in vivo model. Usually, the efficacy of such complex pharmaceuticals is verified either by minimal inhibitory concentration or with optical microbiological detection methods. In both cases, the interaction between cells and drugs should only be regarded as an approximation since it is not directly tested on human cells or still needs to be modified for the according detection method [4]. Thus, the samples are modified and no more natural. Nerveless, a direct adaption of these obtained results is often not possible and not even safe or effective for the patient. In most cases, anticancer agents trigger an apoptotic response of the cells. Hereby, the surface of the cell changed dramatically which can be measured. A promising approach which solve these demand, could be the electronic speckle pattern interferometry (ESPI).

The ESPI is total field measurement technique. Usually, this optical method is utilized for characterization and evaluation of obstructed components in the field of automotive industry or manufacturing system engineering. ESPI allows the examination of thermal impact, nominal tensile stress, shear stress or strain. The method is generally based on the creation of so called speckle interferences. These arise by the illumination of a microrough surfaces with monochromatic, coherent light. Each roughness peaks of the surface are according to Huygens principle the initial point of new elementary weaves. On these peaks, the beam is reflected in different angles which causes the emitted waves to randomly expand in space were the wave front interfere [5]. As a result, a speckle pattern is created which contains the information of the current surface situation. For the evaluation of a surface displacement a second speckle pattern needs to be recorded. Afterwards, both obtained patterns are subtracted on a pixel by pixel basis. The resulting image contains the absolute values of the subtracted pixel intensities. Depending on the applied laser light the ESPI is capable to visualize surface displacements online in a range of 0.01 to $2 \mu \mathrm{m}$ are detectable. This range basically allows the utilization of the method for analysis of biological samples such as single cells, complex cellular structures or even tissue. However, the general ESPI setup had to adapted in order to meet the physical requirements as well as the reduced geometry of biological samples (see Figure 1) [6, 7].

In contrast, speckle pattern resulting from displaced biological samples are referred to as so called biospeckle. In the development of biospeckle, the random scattering of the incoming waves are created by an optical diffuser such as the cellular membrane or cell compartments. Thus, coherent light interacts with each surface of biological material while passing through multiple layers. Therefore, changes or deformations of these layers could be evaluate by ESPI and allows a real time and contact less analyses of cellular state without any additional modification. Thereby, analysis of tissue samples from cancer patients with anticancer drugs could be performed and provide a more realistic prognosis regarding the individual efficacy of applied pharmaceutical. Such insight could be beneficial for the decision making which drug should be applied and consequently prepare the way for a personalized therapeutic approach. 


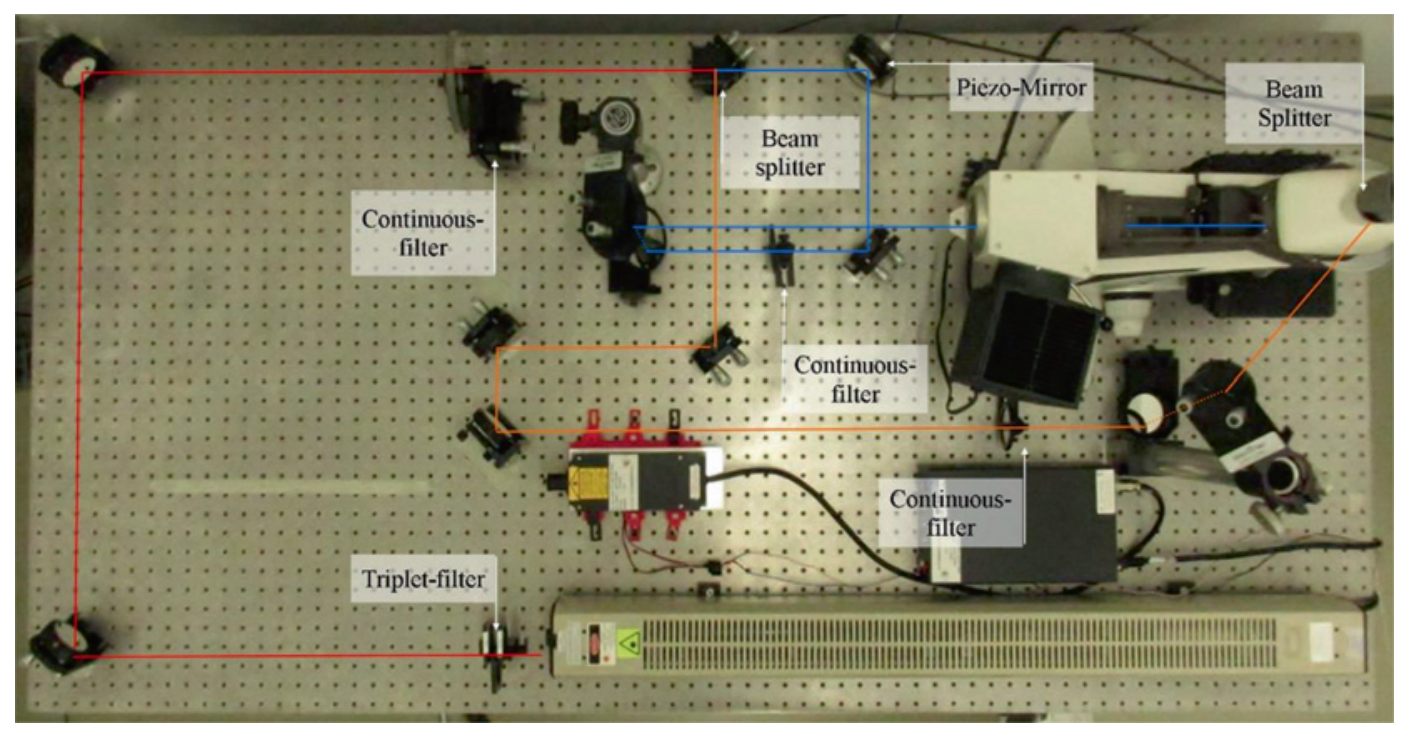

Figure 1: Beam path of the ESPI setup including the undivided laser beam (red), the reference beam (orange) and the object beam (blue).

\section{Methods}

Previous to the initial measurement, HeLa cells and L929 cells were separately cultured on a silicon substrates with an amount of 35000 cells per substrate. After a cultivation period of three days these were transferred into a measurement chamber. $1500 \mu \mathrm{l}$ cultured medium without fetal calf serum and antibiotics was added. In order to measure the displacement of the cellular body the reaction chamber was placed in the experimental setup shown in Figure 1.

The applied EPSI setup is based on a Mach-ZehnderInterferometer and capable to detect out-of-plane displacement. As light source a HeNe laser with a power output of $25 \mathrm{~mW}$, an emitting wavelength of $45 \mathrm{~nm}$ and a traverse mode of TEMOO is used. The laser beam is guided openly over the optical table and separated into the reference beam (blue) and the object beam (orange) at the first beam splitter. Additionally, a piezo-mirror is placed in the path of the object beam and allows the calibration of the system by using the phase-shifting method. In order to visualize the displacement of the biological specimen, the object beam is guided thought the optics of a modified microscope based on a Leica DM/LM. The performed experiments have been carried out using emulsion lenses. After the interaction with the sample the object beam is recombined with the reference beam via another beam splitter and form the speckle pattern in the image plane of an applied CCD camera CS8420c ci. The cellular reaction was initiated by adding of $500 \mu \mathrm{l} \mathrm{Halaven}{ }^{\circledR}\left(1.23 \mathrm{mg} / \mathrm{m}^{2}\right)$. The resulting displacement of the cellular body was obtained in an interval of 5 min using the described ESPI method.
All obtained speckle patterns were evaluated with the software Frames Plus 6.01 and ESPI-Result-Image-Comparser.

\section{Results and discussion}

The experiments regarding the analysis of the apoptotic cellular reaction were performed utulizing a culture medium without fetal bovine serum (FBS). Hereby, the applied dosage of Halaven ${ }^{\circledR}$ corresponds to the therapeutic recommendation of the manufacturer. Figure $2 \mathrm{a}$ to $\mathrm{c}$ shown the obtained states of the induced cellular reaction.

The chemical agent of Halaven ${ }^{\circledR}$, Eribulin, binds to the beta subunits of the tubulins and overlaps the guanosine triphosphate (GTP) binding site. Thus, the tubulin polymerization is inhibited which causes the tubulins to degrade into non-productive aggregates. Thereby, the spindle apparatus can't be formed and inhibits the mitosis which as a consequence induces the apoptosis of the cell [8] as shown in Figure 2. The apoptotic bodies represent itself in form of circular outgrowths of the cell membrane. After 10 min a visible reduction of the cellular body and the formation of apoptotic bodies around the cell could be observed.

During the reduction of the volume the cell furthermore formed streaks on the adhesion medium. These are protein filaments which leave residues on the adhesion medium due to the spontaneous contraction of the cell. In consequence of the cellular reaction, the end point of the apoptotic reaction was identified after $30 \mathrm{~min}$. This is indicated by the completely rounded shape of the cell 

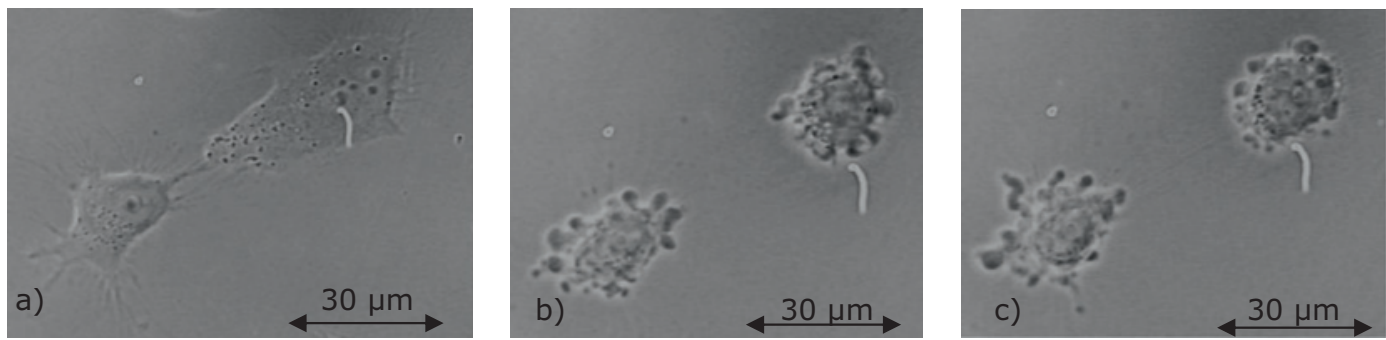

Figure 2: Microscope images of apoptotic stages of the HeLa cell after Halaven ${ }^{\circledR}$ injection. a) Reaction time: 0 min b) reaction time: 10 min c) reaction time: $30 \mathrm{~min}$.
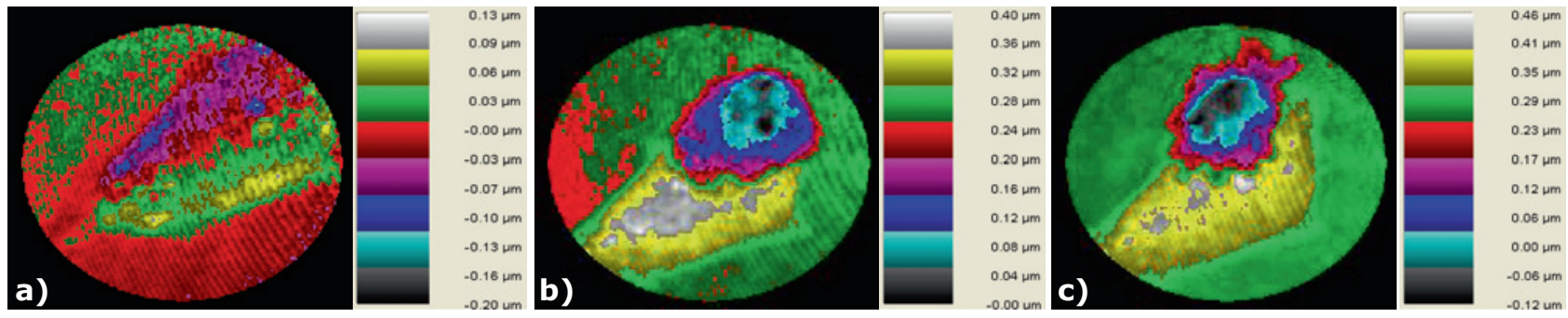

Figure 3: False phase images with color scale of apoptotic stages of the HeLa cell after Halaven ${ }^{\circledR}$ injection. a) reaction time: 5 min b) reaction time: $10 \mathrm{~min} \mathrm{c}$ ) reaction time: $30 \mathrm{~min}$.

and states of secondary necrosis, which are indicated by the disrupted cellular membrane. Defined states of the obtained displacement information are displayed in Figure 3.

Figure 3a displays the analyzed sample cell at an early reaction time of five minutes. While the outer shape of the cellular body seems to be visible no significant deformation was obtained. In comparison, Figure $3 \mathrm{~b}$ contains the deformation of the rounded cell after a reaction time of $10 \mathrm{~min}$. This displacement is indicated by the circular negative displaced area (purple) as well as by the developed positive deformation area (yellow/green). As describe above, in the beginning of the apoptotic reaction the cell body begins to shrink due to the degradation of the cytoskeleton due to the inhibition caused by the Eribulin. In Figure $3 \mathrm{c}$ the increasing of the positive deformation area as a result of the progressing apoptotic reaction is shown. Compared to Figure 3b, the negative displacement is more clearly with different rounded areas. This indicates the arising membrane protrusions. With these results, it was shown that an induced cell reaction can successfully be monitored and validated with ESPI. Based on the obtained deformation a linear scan was placed across the deformed cell (30 $\mathrm{min}$ ) as seen in see Figure 4 with the ESPIResult-Image-Comparser. This self-designed program utilizes the intensity per pixel according to the measurement result and the corresponding color scale to generate the topographic scan.
Figure 4 shows the resulting deformation after $30 \mathrm{~min}$ reaction time. In the sections a and d, the height of the silicon surface is indicated which provide the baseline for this experiment. Section b displays the surface of the apoptotic cell with a total displacement of approximately $0.4 \mu \mathrm{m}$. The alternating course of the curve represents the apoptotic bodies. Furthermore, the c section contains the obtained surface information regarding the initial shape of the cellular body with a positive offset of around $0.1 \mu \mathrm{m}$.

Parallel to the previous described experiments focusing on the behavior of HeLa cells a second cell type, Fibroblasts, was analyzed. Fibroblasts are the main component of connective tissue and the primary source of most extracellular matrix components. Another important function is the production of collagen. In addition, fibroblasts are a key factor in wound healing and also involved in tumor progression [9]. For this reason, the experiment was repeated with fibroblast cell of the cell line L929. The L929 are monolayer growing cells with an approximate cell cycle of $24 \mathrm{~h}$. They are often used for cytotoxicity tests since the cytotoxicity can be directly correlated with the cellular morphology and metabolic activity because these cells have a high cell division rate similar to degenerated cells. Thus, they are effective for degenerate cell experiments in terms of a negative control [10].

As seen in Figure 5, the apoptotic reaction was induced after the addition of halaven. However, the reaction 


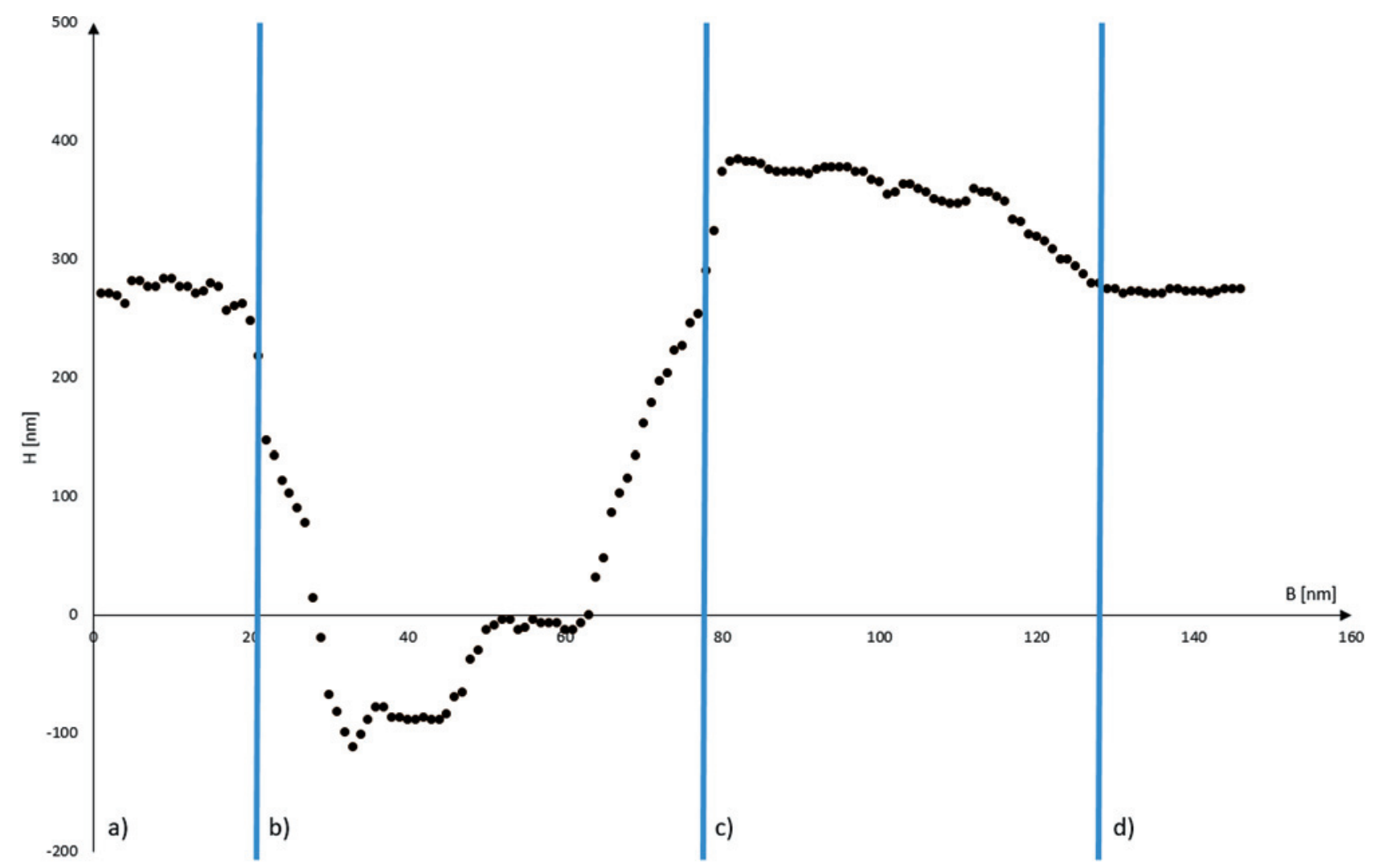

Figure 4: Cellular deformation of the HeLa cell after 30 min reaction time with Halaven ${ }^{\circledR}$. X-axes: displacement width in nm scale; $y$-axes: displacement high in nm scale.
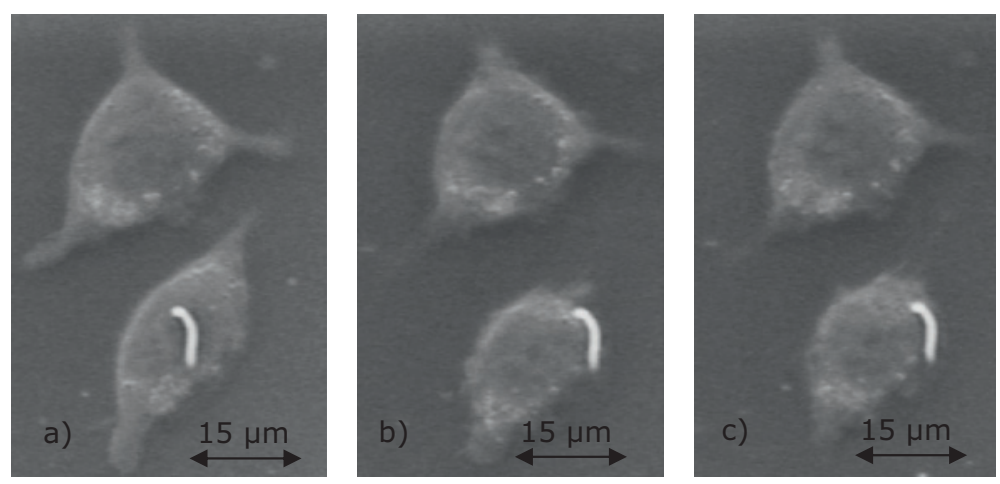

Figure 5: Microscope images of apoptotic stages of the $\mathrm{L} 929$ cell after Halaven ${ }^{\circledR}$ injection. a) Reaction time: $0 \mathrm{~min}$ b) reaction time: $10 \mathrm{~min} c$ ) reaction time: $30 \mathrm{~min}$.

is significantly slower in comparison to the obtained displacement of the HeLa cells. Compared to the HeLa cells, the cellular displacement after a reaction time of $10 \mathrm{~min}$ (see Figure 5b) and $30 \mathrm{~min}$ (see Figure 5c) isn't distinctive visible. Nevertheless, after a total reaction time of $60 \mathrm{~min}$ the apoptotic state of the observed L929 was observed. Overall, only a minimal change of the cell geometry as well as some developed apoptotic corpuscles were obtained. Based on these results it was concluded, that the overall effect of Halaven ${ }^{\circledR}$ was significantly reduced. An exemplary apoptotic reaction of the L929 cells obtained with ESPI are shown in Figure 6.

In Figure 6, both cells display distinctive areas of displacement which are indicated in yellow (positive) and blue (negative). Furthermore, the slow contraction of the cellular body, the loss of the spindle-shaped structure, the formation of the apoptotic bodies are clearly visible over time and shown in Figures 6a to 6c.

This is indicated by circular negative displacements also in the increasing positive deformation area. 

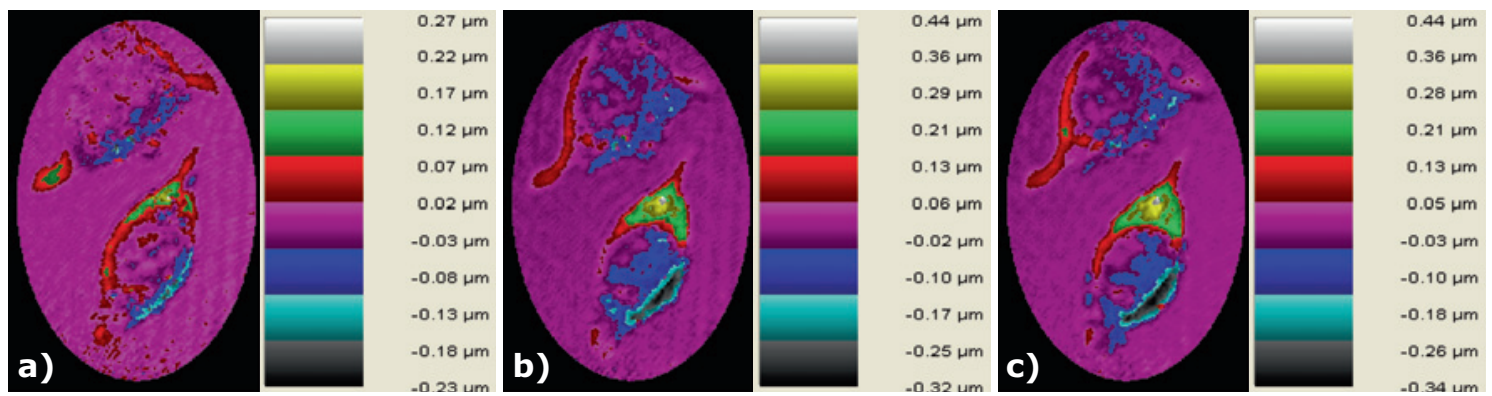

Figure 6: False phase images with color scale of apoptotic stages of the L929 cells after Halaven ${ }^{\circledR}$ injection. a) Reaction time: 5 min b) reaction time: $10 \mathrm{~min}$ c) reaction time: $30 \mathrm{~min}$.

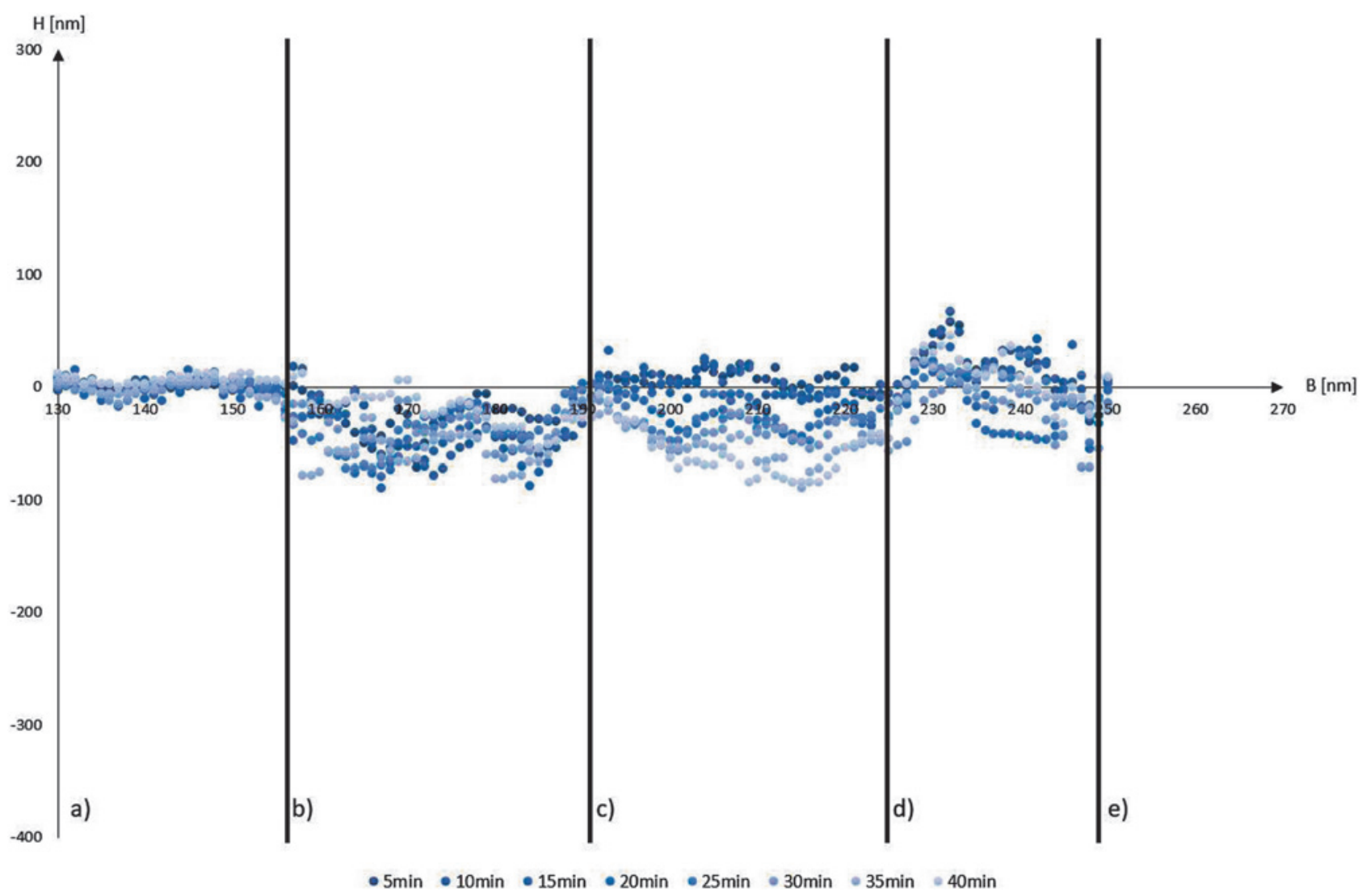

Figure 7: Cellular deformation of the lower $L 929$ cell over the reaction time with Halaven ${ }^{\circledR}$. X-axes: displacement width in nm scale; $y$-axes: displacement high in nm scale.

According to this, the scanning curves of time dependent displacement of the lower cell are shown in Figure 7. Section a represents the surface of the silicon chip without any cells. The obtained displacement in section $\mathrm{b}$ indicates that the lower cell has contracted strongly compared to the initial position. The membrane invaginations formed by the apoptotic reaction are displayed in section c. Section d represents the original cell position and thus indicates the occurred positive surface deformation. In comparison, Figure 8 contains an overlap of multiple scanlines for the upper cell. With advancing apoptosis, the increasing formation of the induced deformation is clearly shown in Figure 8. As in the previous example, section a contains the surface information of the silicone substrate which consequently displays no displacement. In comparison, the other sections $\mathrm{b}, \mathrm{c}$ and d display an alternating patterns for each lines, which indicates the formation of the apoptosis corpuscles. 


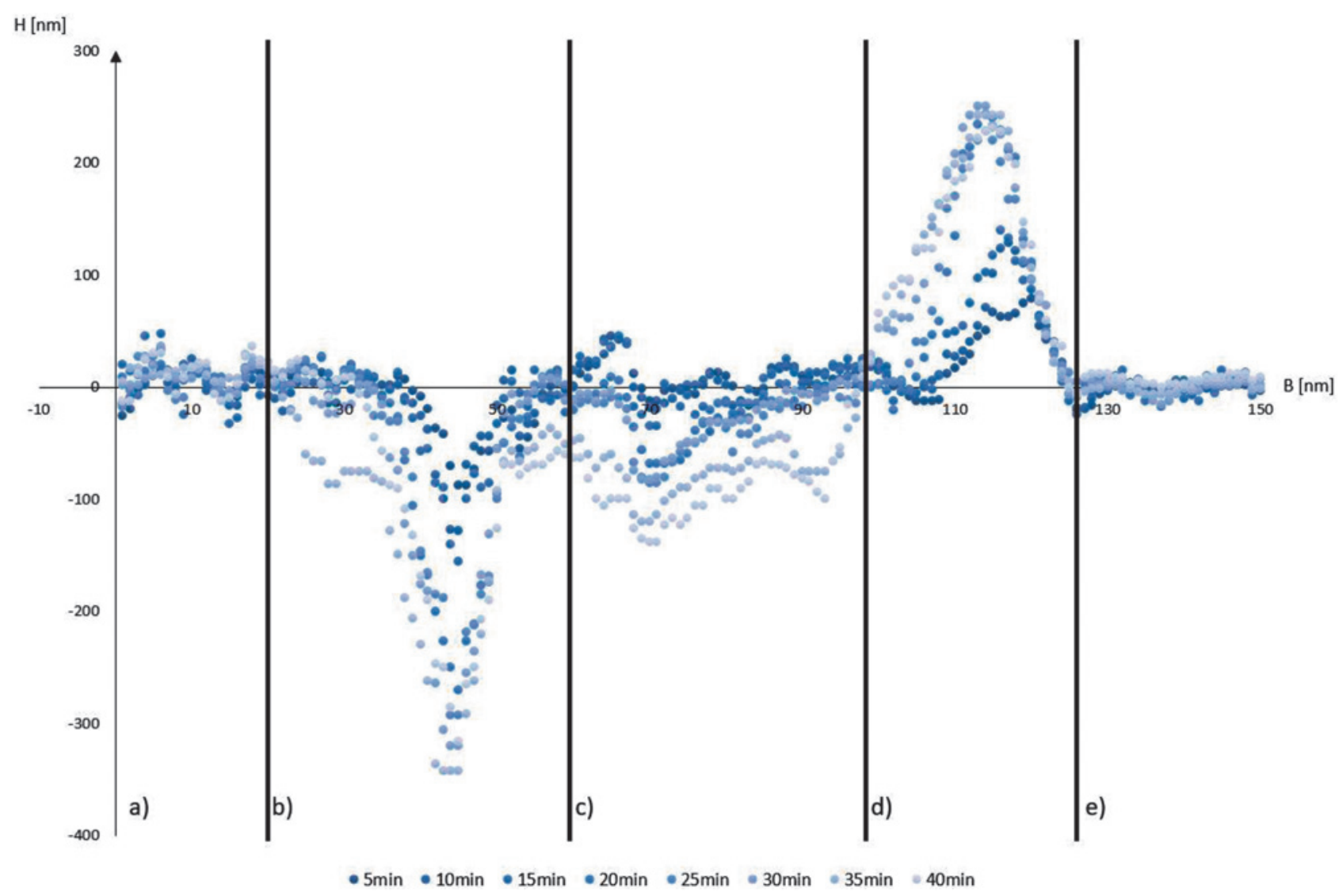

Figure 8: Cellular deformation of the upper $\mathrm{L} 929$ cell over the reaction time with Halaven ${ }^{\circledR}$. X-axes: displacement width in nm scale; $y$-axes: displacement high in nm scale.

\section{Conclusion}

Since the first removal of human epithelial cells from a cervical cancer more than 60 years have passed. With the help of these cells, the first artificial cell line could be established and has been used worldwide by scientists to investigate cellular behavior in various fields of application [11], [12]. However, the complexity of cell interactions still renders a general approach for cell based therapy unreliable and only partial effective depending on the individual state of the patient.

Within this work, a new strategy for the investigation of such a cellular interactions after the application of external stress in form of a cytotoxic agent was demonstrated. After injection of the drug Halaven ${ }^{\circledR}$, an apoptotic reaction of the different cells could be induced while the surface displacement of the cellular body was obtained utilizing the ESPI method.

The main advantages of this method are the abilities to observe the biological samples in real-time, without sample contact and without sample destruction. Furthermore, the application of a modified ESPI setup allows a direct analysis of the cells in medium without additional influence by the measurement procedure. This approach provides a capable method to examine the cells in an almost natural environment which is fundamental to analyze complex cellular interactions in order to develop new therapeutic methods.

\section{References}

1. C. K. Schneider, U. Kalinke, Bundesgesundheitsbl-Gesundheitsforsch - Gesundheitsschutz 2007, DOI https://dx.doi.org/ 10.1007/s00103-007-0331-6, Paul-Ehrlich-Institut, SpringerVerlag, 2007

2. U.S. Public Health Service Guidelines, NCTC clone 929, https://www.lgcstandards-atcc.org/Products/All/CCL-1.aspx? geo_country=de\#generalinformation, 13.07.2017 um 10:56 Uhr

3. Institute of Medicine (US) Committee on Quality of Health Care in America, Washington (DC): National Academies Press (US), 2001

4. Stedman, T. Lathrop, ed. The American heritage Stedman's medical dictionary. Houghton Mifflin, 2004

5. K. S. Samkoe, E. Schultz, Y. Park, D. Fischer, B. W. Pogue, K. Smith, K. M. Tichauer, S. L. Gibbs, “Quantitative imaging 
of intracellular signaling for personalized pancreatic cancer therapy in an in vivo avatar", 2017

6. P. Heerde, "Einsatz der Speckle-Interferometrie für die Bewertung des Spannungs- und Verformungsverhaltens zur materialabhängigen Gestaltoptimierung prothetischer Konstruktionen", http://www.diss.fu-berlin.de/diss/servlets/ MCRFileNodeServlet/FUDISS_derivate_000000005912/ Heerde.pdf, 12.09.2009 um 14:58 Uhr

7. M. Riemenschneider, Echtzeitvermessung dreidimensionaler Objekte mittels Speckle-Interferometrie, Shaker Verlag, Ausgabe 1, 2006

8. T.R. Moore, A simple design for an electronic speckle pattern interferometer, American Journal of Physics 73, 2005

9. K. Theerakittayakorn, T. Bunpraser, Differentiation Capacity of Mouse L929 Fibroblastic Cell Line Compare With Human Dermal Fibroblast, Engineering and Technology International Journal of Medical, Health, Biomedical, Bioengineering and Pharmaceutical Engineering, Ausgabe 5 Nr. 2, World Academy of Science, 2011

10. Eisai GmbH, Dossier zur Nutzenbewertung gemäß §35a SGB V von Lenvatinib, 2015

11. M.-K. Ganten, M. A. Weber, T. M. Ganten, Zelluläre Mechanismen der Tumorresponse, Der Radiologe 48, Ausgabe 9, Springer-Verlag, 2008

12. R. Skloot, Die Unsterblichkeit der Henrietta Lacks, Goldmann Verlag, 2013

\section{Bionotes}

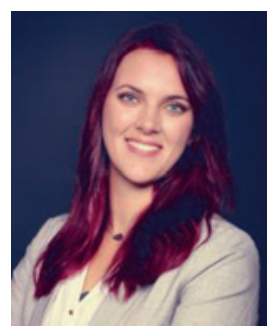

\section{Dr. Josefine Johanna Gottschalk}

Technical University of Applied Science Wildau, Institute for Materials, Development and Production, Hochschulring 1, 15745 Wildau, Germany, +493375 508679 gottschalk@th-wildau.de

Scientific Project Worker, http://www.th-wildau.de/mst

\section{Dr. Carsten Stollfuß}

Technical University of Applied Science Wildau, Institute for Materials, Development and Production, Hochschulring 1, 15745 Wildau, Germany, Phone: +49 3375508253 carsten.stollfuss@th-wildau.de

Scientific Project Worker, http://www.th-wildau.de/mst

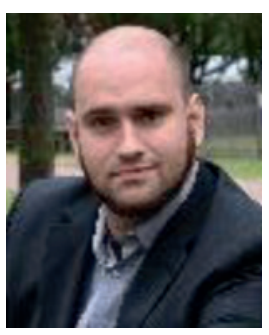

\section{Dr. Kai-Henning Lietzau}

Technical University of Applied Science Wildau, Institute for Materials, Development and Production, Hochschulring 1, 15745 Wildau, Germany, Phone: +493375508487 kai-henning_lietzau@th-wildau.de

Scientific Project Worker, http://www.th-wildau.de/mst

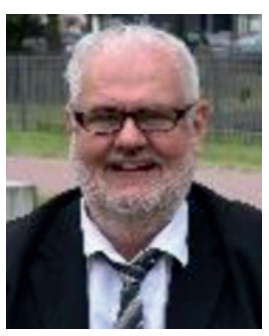

Prof. Dr. rer. nat. Andreas H. Foitzik Technical University of Applied Science Wildau, Institute for Materials, Development and Production, Hochschulring 1, 15745 Wildau, Germany, Phone: +49 3375508178

afoitzik@th-wildau.de

Professor, http://www.th-wildau.de/mst

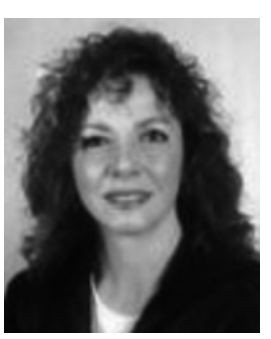

\section{Dr. Maria Richetta}

Department of Industrial Engineering, University of Rome "Tor Vergata", Via del Politecnico 1, 00133 Rome, Italy, Phone: +39 0672597197

richetta@uni-roma2.it

Dottorato di Ricerca in Proprietà Termofisiche dei Materiali, Scientist 